\title{
日本風工学会名誉会員に推挙されて On the Nomination for an Honorary Member of JAWE
}

\author{
前田達夫*
}

Tatsuo MAEDA

このたびは日本風工学会名誉会員に推挙していただき 大変光栄に存じます。推挙していただきました理事会の 皆様に深く感謝いたします。

昭和 49 年に国鉄に入社，昭和 50 年に鉄道技術研究所 に配属になり, その後, 平成 25 年に退職するまで, 一貫 して鉄道の空気力学的課題の現象解明と対策の研究に従 事してきました。風工学との係わりは昭和 61 年 12 月に 発生した強風による余部橋梁列車事故でした。昭和 62 年 に余部事故技術調查委員会が設置され，原因究明と対策 の検討がなされましたが, 委員として, 当時, 京都大学 の光田寧教授, 白石成人教授, 日本大学の塩谷正雄教授, 気象研の花房龍男室長らがおられ，事故調查に関寸る風 洞試験では, 京都大学の松本勝助教授のご指導を受けま した。委員会の重要な結論は,「車両に働く空気力は, 車 両形状のみならず, 橋梁, 築堤などの線路構造物形状に 依存する」というもので, その後の強風時の列車の安全 性に関する空気力学研究の方向性を示唆するものでした。 その方向づけにしたがって実施した研究の成果が平成 14 年度文部科学大臣賞 (研究功績者) につながりました。

平成 4 年に財団法人鉄道総合技術研究所は，新幹線の 高速化，浮上式鉄道の開発を目指して，大型低騒音風洞 の建設を決定しました。そして，風洞建設に関する技術 検討委員会が設置され，鉄道用風洞の規模と性能が議論 されました。委員長の東京大学の中口博名誉教授，その
後の委員長代行の東京大学の佐藤浩教授ら, 委員の方々 のご指導の下，平成 8 年に米原に大型低騒音風洞が完成 しました。平成 11 年には日本風工学会より, 鉄道総合技 術研究所は技術開発賞「大型低騒音風洞の開発」を受賞 しました。風洞の計画，建設から完成後の風洞試験まで 一貫して係われたことは大変うれしいことでした。

研究所に入所した昭和 50 年は山陽新幹線の博多開業の 年であり, 研究所在職中の 38 年間は, 新幹線網が拡大し, 新幹線の速度向上が積極的に行われ，時速 $500 \mathrm{~km} / \mathrm{h}$ を目 指寸浮上式鉄道の研究開発も本格的に行われた時期であ り, トンネル微気圧波, トンネル内の圧力変動, 列車の 空気抵抗, 強風時の車両に働く空気力, 空力騒音をはじ めとする沿線の騒音問題など, 広く浅くなってしまった 面は否めませんが，さまざまな鉄道の空気力学的な課題 の研究に携わることができ, 幸運でした。

翻って, 風工学と関連のある強風時の列車の安全性に 関しては，列車の運転規制と解除をいかに安全に効率よ く行うか, 安全性の評価も含めて, まだまだ多くの研究 課題が残っています。強風の特性, 車両の空気力学的特 性, 車両の運動特性が相互に関係する課題であり, 多く の研究分野を包含寸る風工学にふさわしい研究課題であ ると考えます。鉄道関連の研究者, 風工学の研究者がと もに議論しながら, 本課題に関する研究が進展すること を期待しています。 